\title{
Different aggressive media influence related to selected characteristics of concrete composites investigation
}

\author{
Vlasta Ondrejka Harbulakova • Adriana Estokova • \\ Nadezda Stevulova · Alena Luptakova
}

Received: 9 July 2013/ Accepted: 10 January 2014/Published online: 4 April 2014

(C) The Author(s) 2014. This article is published with open access at Springerlink.com

\begin{abstract}
The loss of mass of concrete matrix and subsequent corrosion of concrete has been reported very often. Aggressive liquids such acids, bases, solutions of salts or aggressive gases as well as microorganisms penetrate the concrete and cause deterioration and biodeterioration, respectively. Presented paper is aimed at investigation of concrete corrosion (chemical as well as biologically induced) activated by influence of different aggressive media. Concrete cylinder samples of a $32 \mathrm{~mm}$ diameter and $15 \mathrm{~mm}$ height were formed as a drilled core from prepared concrete cubes. Concrete samples were exposed to different aggressive media under laboratory conditions (acid mine drainage, cultivation media for different bacteria species, sulphuric acid, aluminium sulphate) as well as in situ (waste water of sewage system in Kosice city) for 3 months. Influence of aggressive media and sulphur-oxidising and sulphate-reducing bacteria on concrete samples has been determined in terms of weight and surface changes of investigated concrete samples and leaching of
\end{abstract}

5th International Congress on Energy and Environmental Engineering and Management (CIIEM).

V. Ondrejka Harbulakova $(\bowtie) \cdot$ A. Estokova $\cdot$ N. Stevulova Institute of Environmental Engineering, Technical University of Kosice, Vysokoskolska 4, Kosice, Slovakia

e-mail: vlasta.harbulakova@gmail.com

\section{A. Estokova}

e-mail: adriana.estokova@tuke.sk

N. Stevulova

e-mail: nadezda.stevulova@tuke.sk

A. Luptakova

Institute of Geotechnics, Slovak Academy of Science,

Watsonova 42, Kosice, Slovakia

e-mail: luptakal@saske.sk the selected ions. The weight changes varied in the range $0.04-3.7 \%$. The visual changes of samples surface were observed. Content of $\mathrm{Ca}, \mathrm{Si}$ and $\mathrm{Fe}$ ions in leachates were measured by X-ray fluorescence methods. Higher percentage of calcium ions released has been measured comparing to silicon ions in all media except for distilled water. The results of elements releasing correspond to results of weight changes of investigated concrete samples.

Keywords Biocorrosion - Leaching - Concrete - SRB · $\mathrm{X}$-ray fluorescence analysis

\section{Introduction}

Concrete materials are in general very durable. However, an aggressive environment can cause deterioration and total collapses of concrete structures long before they have reached the designed end of life. Sulphate environment represents one of the aggressors with significant influence on the durability of concrete. A special type of sulphate deterioration of concrete materials is biocorrosion-the process caused by presence and activities of microorganisms producing sulphuric acid. Studies of the biological processes behind the corrosion of wastewater infrastructure with reference to the role of sulphate-reducing bacteria (SRB) and sulphur-oxidising bacteria (SOB), studies of the chemical effects of sulphates and sulphuric acid on concrete mixes as well as laboratory research methodologies were studied in [1]. Initiating the bacterial processes, sulphates present in the sewer system are converted into the sulphides by sulphate-reducing bacteria such as Desulfovibrio spp. The biofilms with SRB in pipelines with intense corrosion had lower cell numbers but much higher total hydrogenase activity [2]. In the study [3], various 
mechanisms proposed for SRB-induced corrosion such as biocatalytic cathodic sulphate reduction (BCSR); three stages mechanism (Romero mechanism) or sulphide and hydrogen-induced stress corrosion cracking (SCC) were investigated. Nowadays, it is widely accepted that the concentration of Acidithiobacillus thiooxidans (A. thiooxidans) in concrete surface layer may be the best indicator of its biodeterioration intensity [4]. Dubravka et al. [5] has presented a review on microbial processes in municipal waste water collection system, which occur when concrete is exposed to microbacterial and biodegradation favourable environment. Overview [6] has tried to compile the status of knowledge in the field of biodeterioration of concrete, identify areas where more information is needed, and describe nanotechnologies that can be used to obtain the research goals. Zivica and Bajza in [7] described in detail the sources of the gaseous and liquid acidic media, principles of acidic attack and its chemical effects on the attacked material and its resulted degradation. Results of the study on aggressivity of selected carboxylic and sulphonic acids, phenols and some others are published in [8]. Observed increased expansions followed by crack propagation at the action of some media were adjudged to the cooperation of the mechanism. The highest aggression showed the solution of naphtensulphonates and $p$-toluene sulphonic acid [8]. A special type of sulphate deterioration of concrete materials is biocorrosion-the process caused by presence and activities of microorganisms producing sulphuric acid. Five different concrete compositions were tested in [9] including a reference mixture with high sulphate-resistant Portland cement and four different polymer cement concrete with a styrene-acrylic ester polymer, an acrylic polymer, a styrene butadiene polymer and a vinyl copolymer, respectively. The change in $\mathrm{pH}$ of the simulation solutions, changes of $\mathrm{Ca}^{2+}$ concentration of the simulation solution, change in height of the different concrete mixtures and change in weight of the different concrete mixtures were presented. Also results of comparison between the microbiological tests and the chemical tests are published in [9]. Experiments lead to conclusion that concrete composition with the styrene-acrylic ester polymer showed in both tests a higher resistance than the reference, mixture while the compositions with the acrylic polymer and the styrene butadiene polymer had a lower resistance than the reference mixture [9]. In work [10] deterioration mechanisms associated with cementitious materials made with calcium aluminate cement those made with ordinary Portland cement are presented. These samples were exposed to accelerated test relevant to these materials, as well as any other materials that can be used in sewer networks. According to [11, 12] biodeterioration mechanisms of cementitious materials in sewer networks also bring in a succession of microorganisms clearly identified in the case of ordinary Portland cement. Samples were prepared for laboratory and for in situ experiments. Studies carried out in the laboratory indicate that the simple chemical tests (with the addition of sulphuric acid) do not allow estimation of the service life of materials in sewer system [10]. A part of development of a computer model to describe the carrion concrete made with Portland/ Portland blastfurnace cement/concrete with calcium aluminate cement at $\mathrm{pH}$ value between 4.0 and 6.5 are presented in [13]. According to this work, degree of the corrosion is defined by the thickness and porosity of the corroded layer and if abrasion effect occurs, the thickness of removed material. Classification of test methods for concrete corrosion determination and evaluation were presented in [14]. Test methods can be classified according to: the aggressive environment (sewers, underground structures, chemical plants...); the scale of test methods; the type of aggressive species (organic acid, salts, soft water...); parameters to accelerate degradation in simulation tests; the way of measuring the degradation of the specimens (thickness changes, mass loss, expansion, residual strength of specimens, $\mathrm{pH}$ changes of liquid); $\mathrm{Ca}$, $\mathrm{Fe}, \mathrm{Al}, \mathrm{Si}$ and other ions released in liquid. Often combinations of the multiple relevant indicators are necessary [14].

This paper is aimed at the investigation of concrete samples exposed to different aggressive media in laboratory conditions (using different types of liquid media) as well as in situ (waste water of sewage system in Kosice city) for a period of 3 months.

\section{Experimental}

The concrete composites used for the experiments were prepared in accordance with Slovak standard STN EN 206-1-C30/37 using cement CEM I 42.5 R. The composition of experimental mixture is shown in Table 1.

Concrete cylinder samples of a $32 \mathrm{~mm}$ diameter and $15 \mathrm{~mm}$ height were formed as a drilled core from prepared concrete cube $(150 \times 150 \times 150 \mathrm{~mm})$ using drilling

Table 1 Composition of concrete mixture corresponding to $1 \mathrm{~m}^{3}$ of concrete

\begin{tabular}{ll}
\hline Component & Amount \\
\hline Cement CEM I 42.5 R & $410 \mathrm{~kg}$ \\
Water & $168 \mathrm{~L}$ \\
Fr. 0/4 mm & $737 \mathrm{~kg}$ \\
Fr. $4 / 8 \mathrm{~mm}$ & $184 \mathrm{~kg}$ \\
Fr. 8/16 mm & $909 \mathrm{~kg}$ \\
Plasticizer & $2.7 \mathrm{~L}$ \\
\hline
\end{tabular}


Table 2 Characteristics of media

\begin{tabular}{lll}
\hline Conditions & Medium & Concentrations, $\mathrm{pH}$ values \\
\hline Laboratory & $\begin{array}{c}\text { Cultivation media with } \\
\text { A. thiooxidans }\end{array}$ & $c=10 \% ; \mathrm{pH}=2.98$ \\
& Cultivation media with & $c=10 \% ; \mathrm{pH}=7.02$ \\
& Desulfovibrio spp. & \\
& Acid mine drainage with & $\mathrm{pH}=3.7$ \\
& A. thiooxidans & \\
& Sulphuric acid $\mathrm{H}_{2} \mathrm{SO}_{4}$ & $c=0.5 \% ; \mathrm{pH}=0.99$ \\
& Aluminium sulphate & $c=0.5 \% ; \mathrm{pH}=3.22$ \\
& $\mathrm{Al}_{2}\left(\mathrm{SO}_{4}\right)_{3}$ & \\
& Distilled water & $\mathrm{pH}=6.25$ \\
In situ & Waste water & $\mathrm{pH}=7.42$ \\
\hline
\end{tabular}

mechanism STAM. The cylinder specimens were rid of impurity and consequently used for the experiments. The prepared small concrete samples were used for both laboratory and in situ deterioration experiments by immersing the concrete specimens into different aggressive media (Table 2) and into the distilled water as reference medium. Both laboratory and in situ experiments (in waste water in sewage systems of Kosice city) proceeded during 3 months.

Acidithiobacillus thiooxidans is strictly an autotrophic bacteria that oxidise sulphur and thiosulphate to sulphuric acid. Sulphur-oxidising bacteria A. thiooxidans were isolated from the mixed culture obtained from the mine water (the shaft Pech, the locality Smolnik, Eastern Slovakia). Selective nutrient medium 9K [15] was used for the isolation and cultivation of these bacteria at optimal growth temperature of $30{ }^{\circ} \mathrm{C}$ and $\mathrm{pH}$ of 2.5 . The experiments by $A$. thiooxidans proceeded at thermo-reactor at temperature of $30{ }^{\circ} \mathrm{C}$ under aerobic conditions.

Sulphate-reducing bacteria (SRB) Desulfovibrio spp. perform dissimilatory reduction of sulphur compounds such as sulphate, sulphide, thiosulphate and sulphur itself to sulphide. During their growth SRB produce a large amount of hydrogen sulphide that assures the maintenance of anaerobiosis. Desulfovibrio spp. used in experiment were isolated from a mixed culture obtained from the potable mineral water (Gajdovka spring, the locality Kosice-north, Slovakia). The selective nutrient medium DSM63 [16] was used at optimal growth conditions: $\mathrm{pH}$ range from 6.5 to 7.3 and temperature range of $30-37^{\circ} \mathrm{C}$ (mesophilic) and $50-70{ }^{\circ} \mathrm{C}$ (thermophilic). SRB experiment proceeded in glass container under anaerobic condition at temperature of $30^{\circ} \mathrm{C}$. The anaerobic conditions were provided for nitrogen blow in.

The recipient with bacteria contained $180 \mathrm{~mL}$ of selected nutrient medium with $10 \%$ of active bacteria. The concrete samples were placed on the glass basement and
Table 3 Changes in weights of concrete samples

\begin{tabular}{|c|c|c|c|c|c|}
\hline \multirow[t]{2}{*}{ Samples } & \multirow[t]{2}{*}{ Medium } & \multicolumn{4}{|l|}{ Weight } \\
\hline & & $\begin{array}{l}\text { Before } \\
(\mathrm{g})\end{array}$ & $\begin{array}{l}\text { After } \\
(\mathrm{g})\end{array}$ & $\begin{array}{l}\text { Change } \\
(\mathrm{g})\end{array}$ & $\begin{array}{l}\text { Change } \\
(\%)\end{array}$ \\
\hline 1 & $\begin{array}{l}\text { Cultivation media } \\
\text { with } A \text {. } \\
\text { thiooxidans }\end{array}$ & 28.01 & 27.99 & $0.02 \downarrow$ & -0.07 \\
\hline 2 & $\begin{array}{l}\text { Cultivation media } \\
\text { with } \\
\text { Desulfovibrio } \\
\text { spp. }\end{array}$ & 28.59 & 28.60 & $0.01 \uparrow$ & +0.04 \\
\hline 3 & $\begin{array}{l}\text { Acid mine } \\
\text { drainage with } A . \\
\text { thiooxidans }\end{array}$ & 27.44 & 27.42 & $0.08 \downarrow$ & -0.29 \\
\hline 4 & $\begin{array}{l}\text { Sulphuric acid } \\
\mathrm{H}_{2} \mathrm{SO}_{4}\end{array}$ & 27.52 & 28.36 & $0.84 \uparrow$ & +2.96 \\
\hline 5 & $\mathrm{Al}_{2}\left(\mathrm{SO}_{4}\right)_{3}$ & 26.41 & 26.55 & $0.14 \uparrow$ & +0.52 \\
\hline 6 & Distilled water & 27.74 & 27.42 & $0.32 \downarrow$ & -0.17 \\
\hline 7 & Waste water & 27.26 & 28.30 & $1.04 \uparrow$ & +3.70 \\
\hline
\end{tabular}

immersed into medium. The biocorrosion experiments were carried out in the laboratory of the Institute of Geotechnics of the Slovak Academy of Science in Košice.

Acid mine drainage (AMD) originated from the shaft Pech, the locality Smolnik, Eastern Slovakia. Total content of elements in AMD used in the experiment was measured (mg/L): 2,938 sulphates, $307 \mathrm{Fe}, 26 \mathrm{Mn}, 300 \mathrm{Mg}, 119 \mathrm{Ca}$, 5.3 Cu, 10.8 Zn, 77 Al, 0.1 Cd, 0.3 Ni.

Laboratory simulation of chemical corrosion of concrete samples is carried out using sulphuric acid and aluminium sulphate solutions. The volumes of liquids at the beginning of the experiment were $20 \mathrm{~mL}$. Experiments run in several consecutive cycles during 90 days. Each cycle consists of following steps: 7-day exposure of sample to liquid media, removal of the sample from the liquid, 2-day drying of samples at room temperature and afterwards removal of precipitations by little brush, re-immersion of sample into the media and finally adjustment of $\mathrm{pH}$ back to the initial values.

In situ experiments proceeded in the waste water of sewage system in city of Kosice. The parameters of wastewater from gravitational combined sewage system (domestic and storm water) have been tested in Laboratories of Eastern Slovakia Water Supply Company in Koksov Baksa by standard methods according to the national legislative. $\mathrm{pH}$ value of wastewater was measured as 7.42 , measured concentrations were $418.00 \mathrm{mg} / \mathrm{L}$ for total soluble solids, $23.00 \mathrm{mg} / \mathrm{L}$ for total insoluble solids, $1.01 \mathrm{mg} /$ $\mathrm{L}$ for total amount of phosphorus, $8.96 \mathrm{mg} / \mathrm{L}$ for total amount of nitrogen and $8.55 \mathrm{mg} / \mathrm{L}$ of ammonia nitrogen. Biological oxygen demand $\mathrm{BOD}_{5}$ was measured of $17.68 \mathrm{mg} / \mathrm{L}$ and chemical oxygen demand COD (using $\mathrm{Cr}_{2} \mathrm{O}_{7}{ }^{2-}$ ) of $45.93 \mathrm{mg} / \mathrm{L}$. 
Fig. 1 Surface changes of concrete samples before (a) and after the 3-month exposure to cultivation media with $A$. thiooxidans bacteria (b)
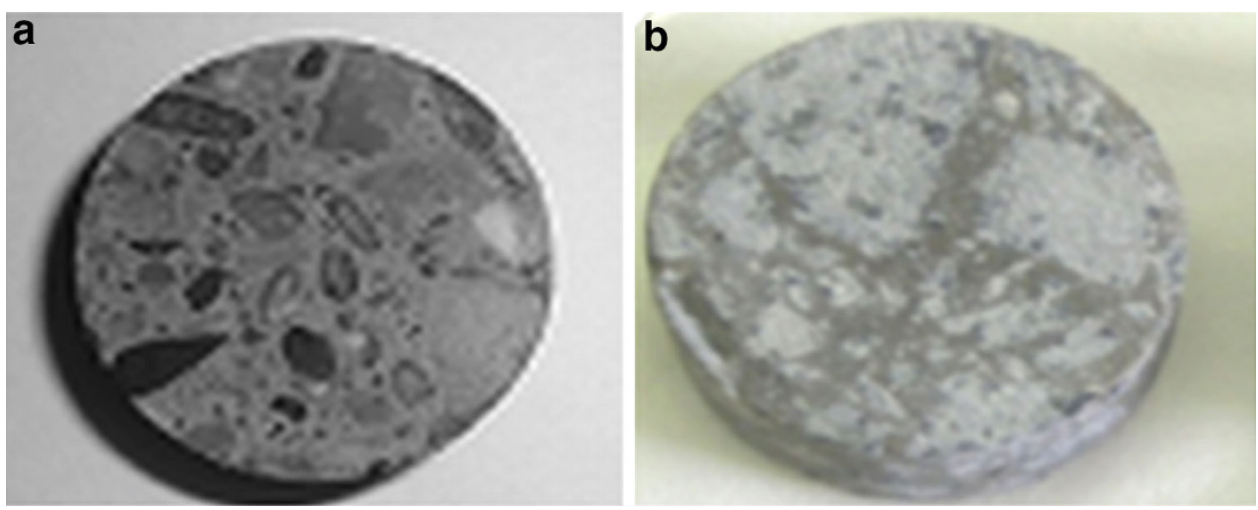

Table 4 Average concentrations of calcium, silicon and iron in concrete samples

\begin{tabular}{lllllll}
\hline Samples & \multicolumn{6}{l}{ Concentration } \\
\cline { 2 - 7 } & $\mathrm{Ca}(\%)$ & $\mathrm{Ca}(\mathrm{g})$ & $\mathrm{Si}(\%)$ & $\mathrm{Si}(\mathrm{g})$ & $\mathrm{Fe}(\%)$ & $\mathrm{Fe}(\mathrm{g})$ \\
\hline 1 & 13.23 & 3.705 & 19.97 & 5.593 & 6.70 & 1.877 \\
2 & 13.23 & 3.782 & 19.97 & 5.709 & 6.70 & 1.916 \\
3 & 13.23 & 3.630 & 19.97 & 5.479 & 6.70 & 1.838 \\
4 & 13.23 & 3.640 & 19.97 & 5.496 & 6.70 & 1.844 \\
5 & 13.23 & 3.494 & 19.97 & 5.274 & 6.70 & 1.769 \\
6 & 13.23 & 3.670 & 19.97 & 5.539 & 6.74 & 1.848 \\
7 & 13.23 & 3.670 & 19.97 & 5.539 & 6.74 & 1.837 \\
\hline
\end{tabular}

Deterioration process of concrete materials was investigated by analysis of basic elements ions (calcium, silicon and iron) releasing into the media as well as by weight changes. The weight changes of concrete samples were determined by gravimetric method measured by analytical balance within $0.00001 \mathrm{~g}$. X-ray fluorescence method was used for analysis of the chemical composition of concrete samples and liquid media. The samples were measured using SPECTRO iQ II (Ametek, Germany) with silicon drift detector SDD with resolution of $145 \mathrm{eV}$ at 10,000 pulses. The primary beam was polarised by Bragg crystal and highly ordered pyrolytic graphite (HOPG) target. The samples were measured during $300 \mathrm{~s}$ at voltage of 25 and $50 \mathrm{kV}$, respectively, at current of 0.5 and $1.0 \mathrm{~mA}$ under helium atmosphere using the standardised method of fundamental parameters for cement pellets and liquids.

\section{Results and discussion}

Weight changes of investigated concrete samples after the exposure to the various aggressive environments are given in Table 3.

Increase and loss in weight of studied concrete samples were observed. The weight changes varied in the range
Table 5 Released ions from concrete samples

\begin{tabular}{llllllll}
\hline Samples & \multicolumn{3}{l}{$\begin{array}{l}\text { Released ions from 1 g of } \\
\text { sample }(\mathrm{mg})\end{array}$} & & \multicolumn{3}{l}{$\begin{array}{l}\text { Percentage releasing from } \\
\text { total content of ions }(\%)\end{array}$} \\
\cline { 2 - 3 } & $\mathrm{Ca}$ & $\mathrm{Si}$ & $\mathrm{Fe}$ & & $\mathrm{Ca}$ & $\mathrm{Si}$ & $\mathrm{Fe}$ \\
\hline 1 & 1.34 & 0.16 & 0.01 & & 1.02 & 0.08 & 0.004 \\
2 & 4.3 & 0.811 & 0.004 & & 3.28 & 0.41 & 0.002 \\
3 & 0.9 & - & 0.007 & & 0.68 & - & 0.003 \\
4 & 31.1 & 15.45 & 17.2 & & 23.5 & 7.76 & 25.67 \\
5 & 6.8 & 9.56 & 0.35 & & 5.2 & 4.79 & 0.52 \\
6 & 2.01 & 7.84 & 0.23 & & 1.5 & 3.92 & 0.35 \\
\hline
\end{tabular}

$0.04-3.7 \%$. The increase in the weight of samples was likely caused by precipitation of new formed compounds on the surface of concrete samples as reported in [4, 17]. The surface changes of studied concrete samples have been observed as it is seen in Fig. 1.

The average concentrations of basic elements (calcium, silicon and iron) in concrete samples before the experiments are summarised in Table 4.

The released amounts of studied ions from the concrete samples exposed to different media under laboratory condition are given in Table 5.

Released amounts of calcium calculated corresponding to $1 \mathrm{~g}$ of concrete sample (Table 5) ranged from $2.01 \mathrm{mg}$ (distilled water) to $31.1 \mathrm{mg}$ (sulphuric acid). It was not possible to calculate the amount of calcium released after the exposure to A. thiooxidans bacteria (samples 1 and 3) due to the decrease of $\mathrm{Ca}$ concentration in leachate after the experiment compared to the input concentration. The decrease of $\mathrm{Ca}$ in leachate was probably caused by the precipitation of new formed calcium compounds (gypsum, ettringite, etc.) on the concrete sample surface during the experiment as referred by De Belie [18]. The most significant deterioration effect in terms of $\mathrm{Ca}$ leaching was observed as expected for sample exposed to sulphuric acid with $23.5 \%$ of calcium released comparing to the total content of calcium. This finding is in accordance to the fact that higher concentrations of sulphate ions correlate with 
more intensive concrete degradation [19]. The lowest leaching ratio of $\mathrm{Ca}$ to total content $(1.5 \%)$ was observed in water environment.

The released amounts of silicon corresponding to $1 \mathrm{~g}$ of concrete sample (Table 5) ranged from $0.16 \mathrm{mg}$ (cultivation media with $A$. thiooxidans) to $15.45 \mathrm{mg}$ (sulphuric acid). In contrast to calcium, the lowest leaching ratio of $\mathrm{Si}$ was observed for sample exposed to cultivation media with A. thiooxidans $(0.08 \%)$; the highest one was detected due to aggressive sulphuric acid influence $(7.76 \%)$. The leaching of $\mathrm{Mg}, \mathrm{Fe}$ and $\mathrm{Si}$ does not at all follow the other, more soluble elements $\mathrm{Ca}, \mathrm{K}, \mathrm{Na}$ and $\mathrm{S}$ [20]. The highest aggressive character of sulphuric acid in terms of calcium and silicon releasing was confirmed as expected.

Released amounts of iron corresponding to $1 \mathrm{~g}$ of concrete sample (Table 5) ranged from $0.01 \mathrm{mg}$ (cultivation media with $A$. thiooxidans) to $17.2 \mathrm{mg}$ (sulphuric acid) as it was in case of calcium. The lowest leaching ratio of Fe was observed for sample exposed to cultivation media with Desulfovibrio spp. (0.02\%); the highest one was detected due to aggressive sulphuric acid influence $(25.67 \%)$.

O'Connel et al. in [1] have outlined a combined approach that considers the interaction between biological and chemical processes. According to this source, chemical tests alone do not fully represent the microbial effects on concrete, although they may help in assessing the types of damage that can occur.

\section{Conclusions}

The more significant deterioration effect was confirmed for samples exposed to sulphuric acid than for samples exposed to biogenic sulphuric acid by both evaluated parameters weight changes and ions releasing. X-ray fluorescence method was used for investigation of the liquid media composition changes in which the concrete samples were exposed. Higher percentage of calcium ions released has been measured comparing to silicon ions in all media except for distilled water. The highest percentage of released calcium, silicon and iron ions was measured in case of samples exposed to sulphuric acid. All results of elements released to leachate correspond to results of weight changes of investigated concrete samples. After the study of visual changes of samples immersed into distilled water, no significant changes were observed.

\section{Findings}

- Deterioration and biodeterioration can be caused when aggressive liquids such acids, bases, solutions of salts of aggressive gases as well as microorganisms influence the penetration the concrete.
- Influence of these media on concrete samples was investigated in laboratory and in real conditions.

- Sulphuric acid, aluminium sulphate, acid mine drainage, waste water were among investigated aggressive liquids.

- The highest percentage of calcium, silicon and iron ions releasing were measured for samples exposed to sulphuric acid.

- Results of elements releasing to leachate measurements correspond to results of weight changes of investigated concrete samples.

- Visual changes on concrete surface were observed.

Acknowledgments The research has been carried out within the Grant No. 2/0166/11 of the Slovak Grant Agency for Science.

Conflict of interest The authors declare that they have no competing interests.

Author's contributions Vlasta Ondrejka Harbulakova has participated in preparing the state of the art for introduction preparation, help with concrete samples preparation, microbiological (laboratory) experiments and in situ experiment. She prepared most of paper. Adriana Estokova has participated in chemical corrosion experiments related to sulphuric aced and aluminium sulphate. She actively worked with X-ray fluorescence methods for results measurement and evaluation. She also prepared significant help with paper preparation. Nadezda Stevulova has participated in "in situ" experiment, she partially designed the course of the studied experiment, evaluated partial results from elements releasing. Alena Luptakova has participated in microbiological experiment with active strains of bacteria. Together with $\mathrm{VOH}$ evaluated results from chemical corrosion experiments. All authors read and approved the final manuscript.

Open Access This article is distributed under the terms of the Creative Commons Attribution License which permits any use, distribution, and reproduction in any medium, provided the original author(s) and the source are credited.

\section{References}

1. O’Connel, M., McNally, C., Richardson, M.G.: Biochemical attack on concrete in wastewater applications: A state of the art review. Cem. Concr. Composites. 32, 479-485 (2010)

2. Voordouw, G., Niviere, V., Ferris, F.G., Fedorak, P.M., Westlake, D.W.S.: Distribution of hydrogenase genes in Desulfovibrio spp. and their use in identification of species from the oil field environment. Appl. Environ. Microbiol. 56(12), 3748-3754 (1990)

3. Kakooei, S., Ismail, M.C., Ariwahjoedi, B.: Mechanisms of microbiologically influenced corrosion: a review. World. Appl. Sci. J. 17(4), 524-531 (2012)

4. Cwalina, B.: Biodeterioration of concrete. Archit. Civ. Eng. Environ. 4, 133-140 (2008)

5. Dubravka, B., Marijana, S., Igor, C.: Review of microbial corrosion of concrete. J. Chin. Ceram. Soc. 38(9), 1741-1745 (2010)

6. George, R.P., Vishwakarma, V., Samal, S.S., Kamachi Mudali, K.: Current understanding and future approaches for controlling microbially influenced concrete corrosion: a review. Concr. Res. Lett. 3(3), 491-506 (2012)

7. Zivica, V., Bajza, A.: Acidic attack of cement based materials-a review. Part 1. Principle of acidic attack. Constr. Build. Mater. 15, 331-340 (2001) 
8. Zivica, V.: Deterioration of cement-based materials due to the action of organic compounds. Constr. Build. Mater. 20, 634-641 (2006)

9. Monteny, J., De Belie, N., Vincke, E., Verstraete, W., Taerwe, L.: Chemical and microbiological tests to simulate sulfuric acid corrosion of polymer-modified concrete. Cem. Concr. Res. 31, 1359-1365 (2001)

10. Herrison, J., van Hullebusch, E.D., Moletta-Denat, M., Taquet, P., Chaussadent, T.: Toward an accelerated biodeterioration test to understand the behaviour of Portland and calcium aluminate cementitious materials in sewer networks. Int Biodeterior Biodegrad (2012). doi:10.1016/j.ibiod.2012.03.007

11. Islander, R.L., Devinny, J.S., Mansfeld, F., Postyn, A., Shih, H.: Microbial ecology of crown corrosion in sewers. J. Environ. Eng. 117, 751-770 (1991)

12. Okabe, S., Odagiri, M., Ito, T., Satoh, H.: Succession of sulphuroxidizing bacteria in the microbial community on corroding concrete in sewer system. Appl. Environ. Microbiol. 73, 971-980 (2007)

13. Beddoe, R.E., Dorner, H.W.: Modelling acid attack on concrete: Part I. The essential mechanisms. Cem. Concr. Res. 35, 2333-2339 (2005)

14. De Belie, N: Evaluation of methods for testing concrete degradation in aggressive solution, Workshop on Performance of Cement based Materials in Aggressive Aqueous Environments-
Characterisation, Modelling, Test Methods and Engineering Aspects, RILEM Publications SARL, pp. 79-90 (2008)

15. Karavajko, GI, Rossi, G, Agate, AD, Groudev, SN, Avakyan, ZA (eds.): Biogeotechnology of metals. Manual. CIP, Centre of projects GKNT, 350, Moscow (1988)

16. Postgate, J.R.: The sulphate reducing bacteria. 2nd Cambridge University Press, New York (1984)

17. Guadalupe, M.A., Gutiérrez-Padilla, D., Bielefeldt, A., Ovtchinnikov, S., Hernandez, M., Silverstein, J.: Biogenic sulfuric acid attack on different types of commercially produced concrete sewer pipes. Cem. Concr. Res. 40, 293-301 (2010)

18. De Belie, N., Monteny, J., Beeldens, A., Vincke, E., Van Gemert, D., Verstraete, W.: Experimental research and prediction of the effect of chemical and biogenic sulfuric acid on different types of commercially produced concrete sewer pipes. Cem. Concr. Res. 34, 2223-2236 (2004)

19. Monteny, J., Vincke, E., Beeldens, A., De Belie, N., Taerwe, L., Van Gemert, D., Verstraete, W.: Chemical, microbiological, and in situ test methods for biogenic sulfuric acid corrosion of concrete. Cem. Concr. Res. 30, 623-634 (2000)

20. EkstrT: Leaching of concrete, Experiments and Modelling, (ed.) KFS AB-Lund Institute of Technology, Division of Building Materials (2001) 